\title{
NARRATIVA TESTEMUNHAL E RELAÇÕES HISTÓRICAS
}

As relações entre autoritarismo e violência na dinâmica da representação literária se articulam de diferentes modos e podem assumir tanto nuances de denúncia e resistência, como registrar marcas de subordinação e silenciamentos. Trata-se de vínculos forjados a partir de situações que revelam, por um lado, a história de violência à qual a humanidade tem sido submetida historicamente e, por outro, a força da literatura na (tentativa de) representação de tais episódios. Como se verifica, a historiografia literária poderia ser tecida a partir de uma história de violência, chacinas, massacres e extermínios sistemáticos.

Nesse sentido, a Revista Eletrônica Literatura e Autoritarismo, em seu 27ํㅡㄴ número, agrega artigos cuja diversidade temática revela o alcance das diferentes formas de autoritarismos e violências perpetuadas ao longo do tempo. Assim, é possível constatar a partir do conjunto de textos reunidos nesta publicação, que as pesquisas englobam tanto a esfera da violência implicada nas relações de gênero e de construção identitária, como a representação da violência em narrativas confessionais, em maioria, ligadas ao exílio e à política de governos autoritários. Assim, há trabalhos que denunciam a violência patriarcal, bem como ensaios que dedicam atenção a temas, como: testemunho, trauma, (auto)exílio e memória.

A partir de um corpus formado por obras da literatura brasileira do século XX, o artigo de Lizandro Carlos Calegari, "Violência, preconceito e exclusão social na Literatura Brasileira do século $X X "$, reflete sobre a violência, 0 preconceito e a exclusão social a queestão submetidos diferentes grupos minoritários, contrariando o argumento que alega que "o Brasil se constitua numa democracia, em que os opostos convivem pacificamente" e afirmando 
que"o que se verifica, em verdade, é uma hierarquização das estruturas do poder".

Na sequência, o artigo de Paula Soria, "Nas tessituras da emergente literatura romani (cigana): subalternidade, gênero e identidade em questão", discute a subalternidade e a construção da identidade de gênero na literatura romani (cigana), considerando que "os escritores romá (ciganos) atuais, de uma forma geral, conseguem produzir textos com um fundo afirmativo e social sem perder em literariedade" o que, por sua vez, "apresenta-se em consonância espontânea com o momento de "despertar étnico" que envolve o povo rom".

Pedro Mandagará, no artigo "Nós, os outros: El otoño del Patriarca", analisa a obra de García Márquez, conferindo destaque ao perfil autoritário do protagonista Patriarca e sua relação com a sociedade latino-americana, observando que "o Patriarca, aparentemente um personagem fechado no texto, se revela uma montagem que encobre pedaços da realidade latino-americana". No entanto, Mandagará problematiza as análises que propõem uma "dissolução do narrador numa textualidade solta quanto da identificação simples com o povo", para pensar o romance "a partir do pronome "nós" (nosotros) em si”.

A literatura de testemunho, que carrega consigo traços de violência e de autoritarismo, é objeto de estudo em: "Perdi as esperanças": o testemunho e a poesia de Alex Polari", de Lívia Volkers e Wilberth Salgueiro. Os autores voltam a atenção para a análise do poema "12.207", presente no livro Inventário de cicatrizes (1978), de Alex Polari, mostrando a força da literatura contra a barbárie e a coisificação, para sustentar a importância do testemunho como recurso no qual "os sobreviventes põem às claras as barbaridades que conheceram nos Lager (campos de concentração) e cujos indícios de existência os responsáveis cuidaram de obliterar".

Em perspectiva similar de investigação, Marta Gouveia de Oliveira Rovai e Eduardo Augusto Carvalho Teixeira, no estudo "Batismo de Sangue: literatura testemunhal como ferramenta do reconhecimento histórico da dor", empreendem a análise do livro Batismo de sangue (1882), de Frei Carlos 
Alberto Libânio Christo, avaliando o papel da memória na luta contra o autoritarismo e refletindo sobre o modo como "as produções testemunhais de sobreviventes de grandes catástrofes não são reflexos da realidade, mas produtos históricos de uma sociedade específica e de agentes discursivos que interferem no próprio processo histórico, como o gênero testemunhal."

Luiza Casanova Machado e Vera Lúcia Lenz Vianna dão prioridade,em seu estudo sobre"O percurso traumático do herói contemporâneo em Longe da água, de Michel Laub", a um aspecto específico na literatura testemunhal: o trauma e suas possibilidades de representação literária.Para isso, as autoras mantêm o foco de análise no protagonista da obra de Michel Laub, e na compreensão que "a tragédia de Longe da Água é individual (o mundo não é tão importante quanto a mea culpa pela morte de um amigo) e não diz respeito aos enigmas enfrentados por toda uma geração".

As características da narrativa confessional e suas relações com o tema do autoritarismo são apresentadas por Lawrence Flores Pereirae João Pedro Wizniewsky Amaral no artigo "A narrativa confessional em Boyhood, de J. M Coetzee: da teoria à prática", no qual analisam a autobiografia do escritor africano, para "verificar como a confissão se faz presente em Boyhood. Assim, esse estudo também é uma apresentação de alguns elementos constituintes de sua seletividade literária na construção de suas autobiografias ficcionais".

Fechando esse número da revista, o artigo "Autoexílio e memória em Dublinenses", de Cristiane Antunes, Rosani Umbach e Sabrina Siqueira, investiga a influência do autoexílio do escritor James Joyce na composição dos contos que compõem a obra Dublinenses (1914). O tema do autoexílio é articulado à questão da memória, a partir do desvendamento das caracterizações assumidas pelos habitantes da cidade natal de Joyce: Dublin, na Irlanda, ressaltando-se que o autor trocava "cartas com amigos e parentes para saber detalhes sobre acontecimentos e moradores de Dublin, e assim transportar para a narrativa dos contos nuances de sua terra natal".

Agradecemos a cada um dos articulistas que disponibilizaram seus ensaios para a organização do número 27 da Revista Literatura $e$ 
Autoritarismo. E esperamos que vocês, leitores, encontrem, nos textos aqui reunidos, fontes para novas perspectivas analíticas da literatura e das relações históricas que ela estabelece com a violência, o autoritarismo e as diversas formas de poder existentes. Boa leitura.

Lizandro Carlos Calegari

Carla Lavorati

Rosani Ketzer Umbach

(Organizadores) 